\title{
Euthanasia and end-of-life practices in France and Germany. A comparative study
}

\author{
Ruth Horn
}

\begin{abstract}
The objective of this paper is to understand from a sociological perspective how the moral question of euthanasia, framed as the "right to die", emerges and is dealt with in society. It takes France and Germany as case studies, two countries in which euthanasia is prohibited and which have similar legislation on the issue. I presuppose that, and explore how, each society has its own specificities in terms of practical, social and political norms that affect the ways in which they deal with these issues. The paper thus seeks to understand how requests for the "right to die" emerge in each society, through both the debate (analysis of daily newspapers, medical and philosophical literature, legal texts) and the practices (ethnographic work in three French and two German hospitals) that elucidate the phenomenon. It does so, however, without attempting to solve the moral question of euthanasia. In spite of the differences observed between these two countries, the central issue at stake in their respective debates is the question of the individual's autonomy to choose the conditions in which he or she wishes to die; these conditions depend, amongst others, on the doctor-patient relationship, the organisation of end-of-life care in hospital settings, and more generally, on the way autonomy is defined and handled in the public debate.
\end{abstract}

This paper presents the results of my PhD: R. Horn. 2009. Le debat sur l'euthanasie et les pratiques en fin de vie en France et en Allemagne. Une étude comparative. Unpublished doctoral dissertation. Ecole des Hautes Etudes en Sciences Sociales. Paris.

R. Horn $(\square)$

Centre for Ethics in Medicine, University of Bristol, Canynge

Hall, 39 Whatley Road, Bristol BS8 2PS, UK

e-mail: ruth.horn@bristol.ac.uk
Keywords Autonomy - Debate · End-of-life practices · Euthanasia $\cdot$ France $\cdot$ Germany $\cdot$ Limitation of medical intervention

\section{Introduction}

In the 1970s in the United States new debates emerged about the limits of medical interventions and about the patients' right of individual decision-making. According to Fox and Swazey the discussion about ethical principles in medicine was generated by different elements, such as: (1) the technical innovations that enabled the maintenance of life in persons that, formerly, would have died; (2) the awareness of the crimes committed by the Nazi doctors; and (3) the American civil rights movements that were occurring during the 1960s and 1970s (Fox and Swazey 2008, pp. 21-32). Since that time, the fact that the life of some resuscitated persons can be maintained although their physical or mental autonomy would not be preserved has been perceived, by some, as a problem. Some such cases have been brought to the public attention, like those of Karen Ann Quinlan (Quinlan, Re 355 A 2 d 664, NJ, 1976) or Nancy Cruzan (Cruzan v Director Missouri Department of Health 1105 Ct 281, 1990), which concerned the right to discontinue life-sustaining treatments. As a result of such experiences, the fear of an extended end-of-life without any quality of life and sometimes dependant on machines emerged within the society. Gradually, a movement for the right to determine the moment of one's own death, largely denominated as euthanasia, developed. Hence the question arose whether society should admit such a right and, if so, on the basis of which arguments (and, equally, which arguments could ground the denial of such a right)? If that question emerged first in the United State, it soon spread 
into other Western countries. Despite this commonality, each country employs different terms and arguments to discuss this question.

In order to highlight advantages and disadvantages of a system that accepts euthanasia or assisted suicide, various reports and studies highlight experiences in the Netherlands, Belgium, Switzerland, Oregon and Washington (Deliens et al. 2003; Smets et al. 2009; Drum et al. 2010). Most of the time, these experiences are judged as "good" or "bad" and serve to justify the positions of adversaries and advocates of euthanasia, such that the morally charged debate is kept alive. However, if we want to understand the complexity of end-of-life situations-that are, I suggest, not limited to the euthanasia question-and if we want to avoid being " 'trapped in [the] binaries' of dichotomized and polarized thinking", it seems relevant to examine and compare the end-of-life practices in countries, such as France and Germany, where euthanasia is not authorised but where there nevertheless exists a debate about end-oflife issues (Fox 2008, p. 25). Such a comparison permits better understanding of how a moral question emerges in public and how it is perceived and discussed as such. Without attempting to solve the euthanasia question, such an analysis can however contribute to further ethical discussions by elaborating contexts, attitudes and practices. In this paper, the term "euthanasia" is reserved to denote the illegal medical practice that aims to hasten deliberately the death of a patient, usually qualified as "active" euthanasia. The other, in most Western countries, legal forms of euthanasia, such as "passive" or "indirect" euthanasia are described in their acts (withdrawing, withholding treatment such as artificial nutrition and hydration, etc.) without being designated as "euthanasia".

\section{Methodology}

In a manner similar to Durkheim's (2007) definition of suicide, euthanasia is here considered as an act that is "performed advisedly" (the actor knows the result of his action) and that in each society is associated with specific problems. This means that euthanasia can be dissociated neither from the moral preoccupations a society associates with it nor from the meaning the acting persons attribute to it (Isambert 1982). With this definition in mind, my objective was to approach euthanasia from two angles: the euthanasia debate itself and the end of life practices underlying this debate in France and Germany. To this purpose, I undertook (1) documentary research and (2) ethnographic research (observations and interviews).

(1) In France I consulted two press reviews in order to trace the development of the debate, to identify the "euthanasia cases" brought to public discussion, and to examine the way in which bills and legislation were presented to the public as well as the terminology used to describe various end-of-life practices (Horn 2006). Both reviews contained articles from leading French newspapers, basically Le Monde, Le Figaro and La Libération. One dossier was assembled by the documentation centre of the Fondation nationale des sciences politiques (Dossier de Presse 1975-2005). This dossier comprises three volumes with an uncounted number of articles regarding "euthanasia", "end of life" or "palliative care", collected from 1975 until 2005. The other dossier is a similar collection of articles additionally comprising professional newspapers and journals such as Le Quotidien du Médecin and Le Bulletin de l'Ordre des Médecins. This dossier was constituted by the documentation centre of the French National Ethics Advisory Committee (Dossier de Presse 19832007). I completed this documentation by consulting the online press archives of Le Monde available from 1987 on (Le Monde 1987-2011). I searched for articles regarding "euthanasie", "end of life" and "palliative care". In Germany I consulted online newspapers and journals such as Die Zeit from 1970 on, Der Spiegel from 1973 on and the Sueddeutsche Zeitung from 1992 on. In addition to this, I read the dossier "Euthanasia, assistance and accompaniment in dying" of the German Medical Association from 1998 to 2007 which reflects different trends amongst the medical community. Finally, I completed this information with relevant legal texts, documents recommending professional guidelines and philosophical literature on the subject in both countries. By comparing the terms used in the debate in each country, the practices qualified as "euthanasia", and the legal situation, I was able to explore the different meanings given to euthanasia and the moral preoccupations that each society associates with it.

(2) The aim of my empirical research was to deepen my understanding of the practical problems raised in end-oflife situations through direct observations and semi-structured qualitative interviews. In order to limit my observations to such situations, I chose to follow palliative care teams specialised in providing care during the last period of life. I concentrated on hospital based teams and consultants because most end-of-life decisions are made in hospital settings (Schindler 2005; Lalande and Veber 2009). The intervention of mobile palliative care teams in other hospital services (oncology, nephrology, cardiology, neurology etc.) enabled me to compare the way in which palliative and non-palliative care professionals handle these situations. In both countries, the hospitals were selected through network sampling. Initial contacts were made with palliative care physicians I had met in the context of previous interdisciplinary collaborations. With a view to compare similar structures, I did my fieldwork only in public university hospitals in both France and Germany. 
Between 2005 and 2007, I observed the daily activity of three palliative care teams in French hospitals and two in Germany. In France, I followed two mobile teams and one palliative care service and, in Germany, two palliative care services that each had a mobile team. In order to observe every day medical practices, the problems that arise at the end of life, and the interactions between different specialists and professionals as well as between professionals and patients/families, I accompanied the palliative care team each time it was on call or went on rounds. I also tried to gain the confidence of the palliative care teams with which I spent my days by having numerous informal discussions regarding my subject of study as well as by sharing in small talk. The particular interest amongst palliative care teams in end-of-life issues and improvement of medical practices facilitated my access to information.

Concerning my presentation, I introduced myself to the hospital teams as a sociologist working on end-of-life practices. When working with the palliative care teams, I conformed to each hospital's usage concerning the use of a white coat by non medical personnel. Equally, I followed the palliative care team's recommendations and was introduced or introduced myself to the patients either as a trainee or as a sociologist interested in the work of palliative care teams. Only rarely did I speak with patients, their families or with professionals during these rounds. Going every day with different members of the team, taking care of different patients, did not always allow me to see the same patients and to get an overall picture of each patient's situation. Therefore I chose to analyse only those cases that I was able to follow from their first contacts with the palliative care team until the end of their care in a palliative care setting. In France, I documented 31 cases and in Germany 52 cases. Twenty-one of the 31 French patients and 24 of the 52 German patients died during my fieldwork. ${ }^{1}$

\footnotetext{
${ }^{1}$ If the number of documented cases does not permit statistical comparisons, one can however suggest some particularities. Proportionally more palliative care patients died in France (21/31) than in Germany (24/52). This may relate to the fact that I spent a longer period with French teams, but also that French doctors refer patients later to palliative care teams than do German doctors. And if I reported more German than French cases, although I spent more time in France, this may be related to two reasons. First, in Germany I observed that professionals working both in palliative care units and as advisors for other units within the same hospital Secondly, in Germany patients stay for a shorter time in palliative care units than in France. German patients are often referred back to their original unit, to hospices or they return home. This suggests that German palliative care teams intervene at an earlier stage, before the patient is in an acute situation, and that they collaborate more intensively with other specialists. As we will see, in France, on the contrary, the intervention of a palliative care team is often accepted only at the "last stage".
}

The observations were completed by 21 interviews $^{2}$ with French doctors and 20 interviews with German doctors. My focus was on the statements and actions of physicians because they take the definitive treatment decisions. For this reason, no interviews were conducted with patients or other health care professionals, although, during the fieldwork, I held many informal discussions with these professionals. Participants were approached directly while I was on rounds with the palliative care teams. Thus only doctors having experience with end-of-life situations have been contacted. Prior to the interviews I explained that I am interested in physicians' attitudes and practices regarding patients with advanced disease or terminal patients in France and in Germany. Additionally, I attended staff meetings of the palliative care team and meetings between the palliative care teams and other hospital teams, as well as meetings between staffs and families. This gave me access to observe diverse situations, conflicts and interactions reflecting the variability of viewpoints regarding one and the same case. Both interviews and observations were analysed according to different themes: doctors' consideration about end-of-life care; attitudes towards pain in patients and pain treatment; criteria for withholding and withdrawing treatment; attitudes towards patients' wishes to die and towards death in general. As Durkheim (2007) discussed in his introduction of Suicide, a single work can never cover all the details of a complex reality. Thus, the present study does not include all relevant actors and situations, but concentrates on certain practices, professionals' justifications of action and contexts in order to emphasise how they generated and still maintain the respective end-of-life debates in France and in Germany.

\section{A comparison between two countries}

The comparative analysis shows that although both countries associate euthanasia with homicide, the ways they discuss these moral issues and the ways in which practical problems at the end-of-life emerge are different. As I will emphasis in this paper, these differences reflect the historical, political and legal contexts that are particular to a country. Thus, one will see that the arguments and terms employed in the debate as well as the questions that arise with regard to the interpretation of law, pertain to different problems: legality and morality of the medical act, in France; respect for the patient's will, in Germany. In the

\footnotetext{
${ }^{2}$ I conducted the interviews in the first language and translated them later. There is no formal requirement in Germany or in France to have a project like this reviewed by an ethics committee. However, access was negotiated with the head of the palliative care team and appropriate standards for observation and interviews set out and observed, including guarantees of the anonymity of participants.
} 
same way, the movements lobbying for a "good" death developed differently. This has had, amongst other things, an influence on the organisation of end-of-life care in each country. I will then show that while the advocates of euthanasia played an important role in the French debate from the mid-1970s on, the palliative care movement gained public attention only a decade later and stayed for a long time on the fringes of the medical community. On the contrary, in post-war Germany, where the idea of euthanasia is rejected by the broad public, the palliative care movement could easily integrate into the clinical structures. One observes equally in each country different medical attitudes towards end-of-life care and, in particular, towards respect for the wishes of terminally ill patients.

More precisely, these differences bring two models of patients' rights to mind, which Dickenson (1999) has discussed in her article about cultural differences within European biomedical ethics. Whereas she defines one model as the "Southern European Model" and the other as the "Western European Model", my study suggests that the difference is not necessarily to be drawn between South and West. France and Germany are two countries that can both be considered as Western European cultures. However, there is a tendency in French clinical settings to consider that "the patient has a positive duty to follow the doctor's instruction", which corresponds to Dickenson's "Southern European Model". This attitude points amongst others to hierarchical and authoritarian structures emerging from the Roman Catholic tradition which, as Hervieu-Léger (2003, p. 199) shows, still influences the organisation of life and death in the secular French society. In contrast, in Germany, there is a tendency to award the patient the "right to override medical opinion and to pursue his or her own notion of individual wellbeing", which can be associated with Dickenson's "Western European Model". This attitude seems also to refer to the influence of Protestantism in Germany which is, as pointed out by Durkheim (2007), characterised by the value of individual liberty and the absence of hierarchic structures. As Dickenson suggests, I emphasise that elements other than the geographic distinction are constitutive of the doctors' attitude towards patients' autonomy at the end of his or her life, such as the history, the organisation of the terminal care and more generally the philosophical tradition of a society which cannot be separated from its religious imprint (Dickenson 1999, p. 255). Finally, my results show that the request for euthanasia (in which another person takes the final act) as the ultimate exercise of liberty appears more often in a society where patients' autonomy has no important weight. In contrast, assisted suicide (in which the person themselves takes the final act) seems to be less considered in such a society than in a society which emphasises individuals' autonomy and personal responsibility.
France: legality and morality of the medical act

The context of the French debate and the legal situation: from medical power over death to doctors' "right to let die"

According to the French Ethics Committee, euthanasia "is the act of a second person that terminates deliberately the life of a person with the intention to bring an end to a situation judged as unbearable" (Comité Consultatif National d'Ethique 2000, p. 10). This definition has been adopted by the Information Committee that presided over the editing of a new law on the rights of terminally ill persons in 2005 (Assemblée Nationale 2004, pp. 141-142). As expressed in the definition, euthanasia is considered as a deliberate "act" that causes the death of a person, what would mean that it is equal to homicide and therefore prohibited, regardless of the actor's motive. ${ }^{3}$ The second person that commits deliberately the act, with the intention to cause the death of the concerned person, is not defined: they could be a doctor, a nurse, a family member or a friend. The definition does not mention the patient's will; it is only stated that the concerned person is in an "unbearable" situation. Yet, the definition does not clarify an important point: who judges that the situation is unbearable-is it the author of the act or the concerned person? Consequently, it is not made explicit whether the act is motivated by the suffering of the sick person or by the suffering of the person that is brought face-to-face with this suffering.

Since the beginning of the debate about euthanasia in France at the end of the 1970s, the press dossier is evidence of the rigidity that is employed to classify any act that does not aim to avoid the death of a sick person as "euthanasia", and so as homicide (Dossier de Presse 1975-2005, 19832007). A large number of cases of "euthanasia" gained publicity in the media-regardless of whether they had actually concerned treatment limitation, pain relief at the end of life, or a deliberate act to hasten death. The professionals too, over a long period, underlined their uncertainty concerning the difference between illegal and legal end-of-life practices (Assemblée Nationale 2004, pp. 234-236). They mentioned particularly doubts about the interpretation of the articles 37 and 38 of the code of medical ethics of 1995 . These two articles were largely

\footnotetext{
3 What counts in French criminal law is the intention of the act and not the motive (article 221-6 Code Pénal). However, the jurisprundence shows that there are rarely convictions for homicide in cases where the death of a patient has been intentionally hastened. Most often, the actor is acquitted or is given a suspected sentence (see the cases of Marie Humbert and Dr Frédéric Chaussoy in the „affaire Vincent Humbert" or the case of Chantal Chanel and Dr Laurence Tramois in the „affaire du Périgueux “. TF1, 2008).
} 
seen as contradictory since, in article 37 , "pain relief" and "treatment withdrawal" were not clearly distinguished from deliberately "hastening death" as prohibited in article 38. However, it seems that the affirmed ambiguity of the code of medical ethics and the resultant uncertainty served to maintain an attitude in favour of life prolongation at "any price", in the sense of "by means of any therapeutic investigation".

In answer to a medical tradition that can be described as "therapeutic activism" at the end of life, two movements developed with a view to countering the so-called "acharnement thérapeutique" ("therapeutic determination or relentlessness" 4 ) and better protecting the autonomy of terminally ill patients. The first was the euthanasia movement, claiming the right to determine one's own death. Since 1980, its advocates are organised in the Association pour le Droit de Mourir en Dignité (ADMD) which is strongly engaged in publicity work. Since the beginning of their activism, they regularly issue public-opinion polls showing that most French people would be permissive towards legislation on euthanasia (ADMD 2007). Another movement goes back to the pioneers of the palliative care and "accompaniment" movement (mouvement de soins palliatifs et d'accompagnement). In France, the hospice movement was never established, amongst others, because of its pejorative associations in the French language: the French word "hospice" recalls previous terminology designating institutions that catered for old and foolish people, orphans, handicapped, and others at the margins of society. For this reason, one prefers to speak about "accompaniment" of the dying person. While they are strictly against euthanasia, they plead, as well as the euthanasia supporters, against "acharnement thérapeutique" and for greater respect of patients' autonomy. Their purpose is to withdraw curative treatment once there is no longer any therapeutic benefit anticipated, and to focus the intervention on appeasement of physical and psychological suffering of terminally ill patients. Since 1983, the French palliative care adherents are organised in different associations, today all brought together in the Société française d'accompagnement et de soins palliatifs (SFAP).

On the political level, the proposals concerning euthanasia legislation have always been rejected. Nevertheless, the criticism of medical activism at the end of life caused a sensation and an answer had to be given to this problem in the face of increasing important publicity in the media. Thus, a series of legislative measures had been taken to develop palliative care from the 1990s (Loi no 91-748

\footnotetext{
4 This is the literal translation of the French expression "acharnement thérapeutique". In the French end-of-life debate, this expression is currently employed when criticising a professional's behaviour. The fact that there is no equal expression either in German or in English suggests a particularity of the French situation.
}

1991; Loi no 99-477 1999; Loi no 2005-370 2005). However, in the first years of their activism, the French palliative care advocates accused clinical doctors of practicing "acharnement thérapeutique" or, in some cases, even of hastening the death of terminally ill patients. ${ }^{5}$

On the other side, professionals working in curative services have long been reserved towards palliative care professionals, and some still seem to be so. In fact, as some doctors from curative services told me, many of them initially believed, and some still believe, that terminal care where "nothing more can be done" cannot be a medical specialisation itself (Mino and Lert 2003). Furthermore, palliative care professionals constantly report resistance to their acceptance by other doctors and, in general, by those in the hospital administration. Often, their teams were, and as I could observe, still are, located far away from the other services or their designation "palliative care" has been changed to the more general designation of "pain treatment". The idea of giving death its own place in a hospital which is supposed to cure illness seemed to be very difficult to accept. Indeed, the integration of palliative care teams in the French clinical setting was difficult and took place gradually. Principally, but not exclusively, mobile palliative care teams were created, without their own hospital beds and under the direction of another hospital service (mostly oncology services). ${ }^{6}$ In 2007 , for example, there were 89 palliative care units and 340 mobile teams, which mean hospital-based palliative care consultation teams, in France (Cabé et al. 2008). One difficulty, amongst others, is that mobile teams without their own fixed service find that they have to intervene as a "foreign" team in another service.

Problems that rise at the end-of-life are not only linked to the patient's situation. One notices that some problems echo the professional's uneasiness when they are confronted with the end of life and questions concerning "good" practices. In France, these problems have been highlighted by different cases, of which Vincent Humbert's, in 2003, was perhaps the most memorable. Mr Humbert, a 21-year-old man, was tetraplegic after a car

\footnotetext{
${ }_{5}$ In an article published January 6, 1984, in Le Monde, Patrick Verspieren, Jesuit Father and "founder" of the French palliative care movement, criticises the attitudes of "most" doctors concerning their respect of terminally ill patients. He denounces the fact that in French hospitals „euthanasia has become currently and systematically [...] the usual medication at the last stage of life.

${ }^{6}$ If in UK as well, there are palliative care consultation teams rather than palliative care units within the hospitals, the situation cannot be compared to France. The development of the English hospice movement and the important number of hospices and their intense collaboration with hospital doctors has suggested for a long time that there is no need for development of palliative care within hospital settings. However, this does not mean that this development has not created certain problems.
} 
accident. Since doctors established that there would not be any chance of improvement in his state, Mr Humbert sent a letter to the French president in which he claimed the right to access to euthanasia. The demand was refused. His mother, Marie Humbert, then injected him with a high dose of barbiturates that plunged her son into a coma. The doctors tried to reanimate Mr Humbert until the department head, Dr Frédéric Chaussoy, decided to withdraw the lifesustaining treatment. However, to ensure that Mr Humbert would not continue to live in a persistent vegetative state, Dr Chaussoy decided to inject him with potassium chloride. The use of this substance is formally prohibited by the French reanimation guidelines, and by law, because it immediately causes death. After Mr Humbert's death, Marie Humbert was incriminated for "administration of toxic substances", and Dr Chaussoy for "poisoning with premeditation". Both accused had always defended their acts, provoking a large ethical and legislative debate about the issue of euthanasia. Finally, the case was dismissed in 2006 with neither being found guilty of a crime.

The enormous media coverage of this case lead to the creation of an Information Commission instructed to establish a report that provided the basis of the new law voted on 22th April 2005 (Loi no 2005-370 2005). This law rejects any act that "provokes death" but establishes the right to "let die" a terminally ill patient. Furthermore, the law generally defines which practices at the end-of-life are authorised and which are prohibited and emphasises the necessity of collegial procedures during decision-making. While the law before 2005 said that a patient can refuse "a" treatment (article 11, Loi no 2002-303 2002, previous article L.1111-4 CSP), the new legislation makes also explicit that every terminally ill patient has the right to refuse "every" treatment, including artificial alimentation and hydration. The doctor is however not constrained to accept such a request but should "do all that is possible in order to convince the patient" to continue the treatment when the refusal endangers the patient's life (article 3, Loi no 2005-370 2005, current article L.1111-4 CSP). It is not specified what is meant by doing "all that is possible". Amongst others, this is one of the reasons why some French lawyers have a critical eye on the new law. Thouvenin, for example, notices that the law fixes in place a new framework for medical practices at the end-of-life, rather than a framework for respecting patients' autonomy (Thouvenin 2008, pp. 404-405).

Doctors' attitudes in France: uneasiness towards medical inefficiency

My fieldwork started just a couple of months after the law came into force, and it showed that new legislation does not change immediately established attitudes and habits.
The observations and interviews have shown the difficulty French doctors find in withdrawing treatment and in facing the idea that there is "nothing more to do", in terms of curing a patient and avoiding his death. This finding recalls Crane's study about the sanctity of social life (2009, pp. 137-179) in which she observed that doctors with a catholic background, as is the case in France, have a more "active" attitude at the end-of-life than doctors with a protestant background. Many of the French doctors told me that they experience these situations as a "personal failure". When I asked whether a treatment could be maintained even if there was to be no more benefit to the patient and that individual is at his or her final stage of life, a French doctor explained:

One can always offer a treatment and some patients always believe in treatments. And it is normal that in most cases, we maintain a maximal medical treatment, regardless of whether we do it for us or for the patient. [...] One shouldn't deprive a patient of a treatment.

In this case, the doctor shows that a so called "maximal" therapy is not only in the patients' interest but also in their own interest. And another French doctor told me why his patients do not request the discontinuation of treatments:

I have a tendency to treat my patients a lot. So, for them, I incarnate a very active approach and it is just normal that they adhere to my treatment. [...] We [doctors] are like a shaman for the patient. We have a great power within the society. One says that doctors lose their power, but in fact, very few patients question this power.

Later, I observed that this same doctor continued to administer chemotherapy to a patient who was in a seriously advanced stage of her illness until she died. Certainly, this is an extreme example but the doctor's affirmation reflects an attitude I could observe in other cases. It appears that there is a certain tendency amongst French doctors to do everything that is possible to delay the death of a patient - even if the patient may die during their intervention. Death that occurs during an "active" treatment is then less perceived as a "personal failure" than death that occurs after having withdrawn a treatment. In the first case, the doctor can ignore the approaching death, while in the second case the doctor needs to be able to anticipate the patient's death. This latter attitude is in contrast to the palliative care approach.

While most French doctors wished to have the support of a mobile palliative care team, several of them attested to their difficulties with integrating an external team into their work and to anticipate the worsening condition of a patient. Thus, a French doctor from a curative service told me how 
much he senses the intervention of these teams as invasive and troubling:

I don't like the palliative care teams that come to change the treatment of patients they don't really know. [...] They take possession of my patients. They talk with them about their death and two days later my patients really die! [...] They are like the crows over the cadaver.

Such a perception of palliative care teams has been confirmed by other French doctors and nurses. They complained that these mobile teams give "good advice how to do things better", but in fact "they are far away from the daily problems" in the care of seriously sick patients. Hence, the fact that mobile teams do not have their own service to take care of patients presents a problem, first for their integration into the hospital setting and, second for the patients' terminal care. The French organisation of palliative care in mobile teams rather than autonomous services implies that terminally ill patients often stay in curative services. It seems, however, that the rhythm of curative teams and the meaning they accord to their daily activities are hardly adapted to the needs of a dying person.

Consequently, French doctors providing curative services are often faced with terminally ill patients and claim to be particularly worried about the physical and psychological suffering of those patients. My analysis of the interviews I conducted suggests that professionals who perceived suffering as unbearable are at least partly revealing or echoing their own uneasiness towards death and the ineffectiveness of their treatment. Yet, I noticed also that their wish to relieve pain is inhibited by their fear of employing strong painkillers, which might risk producing respiratory depression. Most of the physicians equated this so called secondary effect with euthanasia, the illegal act of killing a patient. (As I will later show, this claim is often misinterpreted or over-stated.) In other cases, the desire to relieve pain, so to intervene efficiently, seemed to be so strong that certain French doctors vouched that they deliberately hasten death in order to achieve this objective:

I think as a doctor, you shouldn't say that you are completely against euthanasia. Everybody knows that some situations are so difficult that you can't act differently.

Another physician explained to me the importance of distinguishing sometimes between one's role as a doctor who should not cause death and one's role as a private person, as an ultimate friend to his patients, which justifies, for this doctor, acting to "hasten the death" of a patient under certain circumstances. Similarly, another French physician told me without hesitation of their experiences in hastening the death of patients:
Do you know what it means to 'put the syringe'? [...] I did it as a young trainee, later as a chief at [hospital $\mathrm{X}$. I did it several times [...] for incompetent patients, because it was unbearable. I did it in accordance with the family, in accordance with myself. [...]

It was not easy but I didn't come into a moral conflict. It was only discontinuing that condition. [...] Before, it was me who injected the syringe full with potassium chloride, today I can ask the nurses to simply increase the morphine doses. What we do [today] in a hidden way is the same we did before.

Indeed, I took notice of several cases where patients died during the night after a doctor had ordered an extreme increase of painkillers in order "to finish this suffering", as the nurses interpreted and reported to the palliative care teams. The aforementioned doctor expressed their difficulty with alleviating the suffering of a patient, but also explained that they only hastened the death of incompetent patients. For this doctor, no conflict of values was perceived. By explaining further that they would not hasten death at a competent person's request, this doctor attests to the sovereignty of medical decisions. Furthermore, the doctor's statement suggests the possible proximity between an analgesic treatment and an act that is designed to hasten death by employing an overdose of painkillers. In order to distinguish these two actions - the first one legal, the second associated with homicide-the doctrine of double effect has been introduced; that means that the secondary, non-intended effect of painkillers supposed to cause respiratory depression is considered legitimate (Dickenson, Huxtable and Parker 2010, pp. 20-21). However, some studies show that opioids or sedatives (benzodiazepines) have no life-shortening effect if administered in an appropriate way i.e. if they are gradually adapted to the degree of pain (Thorns and Sykes 2000, 2003). For that reason, the question arises whether it is still adequate to speak of the double effect of painkillers. However, the myth beyond these substances persists and while certain doctors prefer, by precaution, not to employ high doses of painkillers, others employ them in an excessive way in order to hasten death.

If French doctors attest to an attitude that estimates therapeutic efficiency and generally therapeutic interventions, it seems that this dimension, that I will denominate "active", has also had an effect on patients-and in a larger sense on their loved ones ${ }^{7}$ and the public debate. That is to say, certain persons who estimate a situation as

\footnotetext{
7 A study of Courtas (1991) shows that most of the members of the French association for the right-to-die (ADMD) leading the euthanasia debate did see their loved ones die under "difficult and awful conditions".
} 
unbearable may consider that it is for the doctors to prove their "effectiveness". They may then request that the doctor brings an end to suffering by bringing an end to a life that appears to be unbearable. Without having any relevant national statistics, I observed during my work in French hospitals 5 patients (of 31) who requested to be helped to die by the doctor's hand; 3 other patients expressed their wish to die without however addressing an explicit request to their doctor. In 4 other cases, nurses told the palliative care team that patients died shortly after analgesics had been increased; the situation of these patients had been judged as unbearable by the medical staff. I will return to this observation. Before doing so, I will move in the next section to consider how these issues are framed and dealt with in Germany.

\section{Germany: respecting the patient's will}

The context of the German debate and the legal situation: from "euthanasia" to "assistance in dying"

In Germany, the word "euthanasia" is constantly associated with the crimes that doctors committed during the Nazi period and remains a strict taboo within the society and amongst physicians. Since the Legislative Days in 1947, when it was stated that "in Germany, there shall never again emerge any idea concerning euthanasia, not even in a discussion" (Generaljustizdirektion 1947), lawyers, politicians, physicians and many public authorities never cease to underline this sentiment (Deutsches Ärzteblatt, 1998-2007). Thus, in order to enable any discussion about pertinent medical practices at the end of life, in the international debate often classified as active or passive euthanasia, it has been necessary to substitute the word "euthanasia". The expression "assistance to die" (Sterbehilfe) has therefore been introduced into the German debate. As with euthanasia, "assistance to die" can be classified as "active" or "passive". "Active assistance to die" is not a legal term but associated, like "active euthanasia" in France, with any act that aims to kill another person and is therefore assimilated to homicide. The law prohibiting homicide ( $\$ 216 \mathrm{StGB}$ ) like any other law, relies on the German constitution from 1949, named "fundamental law" (Grundgesetz). The first constitutional principle is human dignity (article $1 \mathrm{GG}$ ), which must be respected and protected by the authorities. The second principle guarantees the right of free development of the individual (article 2 I GG) and the right to life and physical integrity (article 2 II GG).

The definition of "active assistance to die" given by the German Ethics Committee takes into account the importance accorded to human dignity by underlining the right of autonomy and respect for the individual's will, both of which constitute the principle of dignity (Nationaler Ethikrat 2006, p. 50). Then, according to the definition, "active assistance to die" represents any action that tends to hasten the death of a person with her "explicit or presumed consent". In spite of the reference to the individual's consent, such an act remains prohibited because it constitutes homicide - an act committed by a second person. As the lawyer Hufen shows, in German law, the concept of individual autonomy is limited by the right of autonomy and the freedom of conscience of the second person (Hufen 2005, pp. 84-85). Hufen points out further that this understanding of autonomy refers to Kant (1998), whose categorical imperative holds that morality relies not on the consequences of an action but on whether an action is right or wrong for its own sake. This sort of reasoning helps explain why the State, which is generally obligated to protect the individual's liberty against public interventions, has the right to intervene and to prohibit a second person from bringing the life of an individual to an end. If the strong value of autonomy in Germany is not enough to legally allow euthanasia, while countries like the Netherlands legally allow euthanasia as an expression of selfdetermination, this seems then to refer, amongst others, to two different concepts of autonomy: "responsible autonomy" in a Kantian sense and "liberal autonomy" as defined by Mill (2005), who considers that individuals are free to do anything they like as long as this does not harm others.

Apart from the euthanasia taboo, when one traces the German cases dealing with end-of-life practices, one encounters a jurisprudence which is largely in favour of respect for the patient's will. In numerous conflicts concerning treatment withdrawal, at patients' or their family's demands in the face of the physicians' wishes, the juridical decisions have emphasised the primacy of the patient's will (Bundesgerichtshof. 1StR 357/94. 13.9.1994; Oberlandesgericht Frankfurt a.M.. $20 \mathrm{~W}$ 224/98. 5.8.1998; Bundesgerichtshof. XII ZB 2/03. 17.03.2003). At this point, one ought briefly to note that there is a longer tradition in German law of favouring patients' autonomy. As the historian Maehle (2009) shows, self-determination assumed an important place in the legal debate during Imperial Germany from the 1890 s on. At this time, the majority of lawyers associated a medical intervention without a patient's consent with infringement of physical integrity ( $\$ 223$ of the penal Code of 1871). However, doctors in this period were largely influenced by the paternalistic model and did not agree with this interpretation. The patient's right to self-determination remained thus a principally rhetorical right.

The contemporary German debate concerns, since the 1990s, the legal status of advance directives, whose intent 
is to enable unconscious patients to influence the medical decisions. A law, passed on 18 June 2009, specifies the doctors' obligations to respect these directives without limitation of their reach; in other words, without restriction where, for example, the patient is at the end of his or her life (Drittes Gesetz zur Änderung des Betreuungsrechts 2009). Furthermore, the position in favour of patient selfdetermination gave rise to a debate on assisted suicide (an act where the person themselves take a lethal substance), while any discussion about euthanasia (an act where the doctor injects a lethal substance) remains a taboo. This debate was largely animated by the opening of a German section of the Swiss organisation Dignitas in Hannover in 2005 (Lipp 2011). The German Dignitas cannot deliver lethal substances but facilitates German patients' contact with the Swiss organisation. Whereas assistance in suicide in itself is not illegal in German law, a doctor has no legal right to provide a patient with a lethal substance. However, a study from 2009 reveals that $37 \%$ of German doctors think that assisted suicide may be acceptable under certain circumstances and 30\% would approve legislation on assisted suicide. Only $17 \%$ of doctors would approve euthanasia legislation. (Allensbacher Archiv 2009) As a consequence of these data and more generally of respect for autonomy, the German Medical Association in its new guidelines of 2011, no longer considers assisted suicide to be "against the medical ethos" but simply states that it is "not a doctor's duty" to assist with suicide (Bundesärztekammer 2011). The Medical Association reminds its members, however, that any medical act that aims to hasten a patient's death remains impermissible. Furthermore, the statement of the Medical Association does not modify the legal prohibition on delivering a lethal substance.

The German priority given to respecting the patient's will points to: (1) a philosophical Kantian tradition according to which the autonomy of the individual's will is the fundamental principle of all moral laws; (2) the recent German history, that is to say the medical experiments and the euthanasia practices committed by the Nazis on a captive and non-consenting population, whence result the ethical principles fixed in the Code of Nuremberg from 1947; and (3) the influence of American bioethics. The German debate about end-of-life problems emerges, as in France, in the 1970s as a result of the media coverage of the American affairs, but the American discussions seem to have a stronger impact on the German than on the French controversy. However, in spite of the importance of patient autonomy, the German concept of autonomy as well as the historical experience does not encourage a step towards euthanasia.

The discussions about medical decision-making at the end of life and about patients' rights generated in Germany, as well as in France, a movement in favour of voluntary death, generally denoted as euthanasia. However, any proposition in these terms is rejected by large parts of the German population. Despite this, the introduction of the term "assistance to die" as well as the attention given to respect for the patient's will made possible a wider debate and reflection upon end-of-life problems. In this atmosphere favourable to respecting a patient's autonomy, but opposed to any act that would hasten his death, the palliative care approach could develop quite easily. Contrary to France where the palliative care and accompaniment movement ("mouvement de soins palliatifs et d'accomagnement") developed as one single movement, in Germany palliative medicine developed in parallel to the hospice movement which is organised in associations. In Germany, hospices take care of mostly terminally ill persons and are managed by nurses and volunteers, outside of medical settings; doctors work only temporarily there and on a voluntary basis. In the beginning, hospice work was received with some reluctance within a population that had long considered these institutions sad "death clinics" (Seitz and Seitz 2004, p. 143). In spite of this, palliative medicine could develop separately as a new medical specialisation. The medical milieu in post-war Germany, sensitive to the question about excessive medical treatment and the patient's will, was rather open towards this specialisation. For their part, the palliative care professionals rarely adopted a militant position or criticised the practices of their colleagues. They presented their approach, rather than as an antidote, as a logical continuation of caring for patients that no longer benefit from other specialisations. Thus, palliative medicine has been integrated in the German clinical setting, like any other specialisation, as fixed units that come with their own hospital beds. In 2007, there were 156 palliative care services, each with a mobile team, that offer palliative care consultation in other, curative, services. Additionally, the care of terminally ill patients is provided by hospices, numbering 158 in 2007 (Deutsche Hospizstiftung 2008, p. 4).

The attitudes of German doctors: priority of the patient's will

During my ethnographic work, I noted that, in spite of the asymmetry of the doctor-patient relationship, German physicians aim constantly to rely on the patient's will in order to justify their practices and decisions. This reflects certainly the weight of the history, but also the force of juridical rules and a certain understanding of the concept of autonomy in Germany that relies on the Kantian idea that the self-determining individual takes control over the moral value of their action. Respecting both the patient's will and the prohibition of homicide, German professionals rarely question the prohibition on euthanasia. They calmly admit 
that even if one can ease pain, at least psychological suffering at the end of life can never be completely relieved. Thus, doctors have to accept their impotence in some situations and suffering does not justify euthanasia, as one doctor explains:

The debate about [active] assistance in dying emphasises more the problems of healthy persons than those of sick persons. Those who are not sick imagine the distress of an ill person and think that it is so unbearable that they would feel better if they could be sure about a last resort in case of urgency. Persons who are really ill feel these things often differently. And if you explain to them that you can't hasten their death but that you'll do everything possible to assuage their pain and sorrow they are reassured. For sure, some persons decide to suicide if there is no hope of cure. But this happens rarely. And one couldn't diminish their distress with a modification of the law. [...] When someone has a tumour, the question is not whether the person dies two weeks earlier or later. Other questions arise. And this does not justify abolishing an important limit in our legislation. I think the most important thing is that the patient gets faithful and complete information for that he or she can decide what he or she wants us to do in a certain situation.

Vis-à-vis incurable and terminally ill patients, the majority of German physicians recognise the importance of guaranteeing the autonomy of these patients. Therefore, most of these doctors are favourable to their terminally ill patients wishing to withdraw treatment, rather than maintaining false hopes of a cure.

We have to be conscientious that everybody defines the quality of life in an individual way and that we can't affirm that one certain decision is the right one.

And other doctors confirm the priority of free choice and that nobody should try to convince the patient by reference to only medical criteria.

I have no problem in discontinuing curative treatments if the patient wishes that. The German constitutional law specifies the inviolability of the human dignity. And this is the first premise for me. We can show only alternatives but I would never try to convince a patient. If he or she really doesn't want further treatment, I can live with such a decision. I mean, we are all free and we have to acknowledge the liberty of all. If a patient comes and says, 'I came to get your professional advice' and he refuses my advice, this is difficult for me but I accept it. My human duty obliges me to accept what the patient wants. I can only advise and help him or her to come to a decision but if he or she makes another decision than me, I have to live with this - and I can do it quite well.

The affirmation of this physician testifies to another extreme mindset concerning medical power than the French doctor who described doctors as the "shamans". However, in cases where the patient lacks capacity, some German doctors hesitate to discontinue life-sustaining treatments, even if the patient's wish is known by a written declaration or a statement that has been made previously. Some of them suspect that the patient may have changed their view. Thus, some doctors told me that it is very difficult to "switch off" the ventilator when they are not sure whether that would be the patient's wish in this concrete situation. In such situations, some doctors reported that they may feel actively implicated in the death of the patient, even if they know theoretically that this is not the case. While some French doctors testified to no moral conflict when they hasten the death of incapable patients, German doctors appear very concerned about their practices when the patient is not able to consent directly. It seems then that the confidence in their acts and their affirmed calmness rely mainly on a clearly expressed wish from the patient. This is to say, the patient's will provides the moral and legal justification for their end-of-life practices.

Another reason why German doctors seem to approach end-of-life issues rather with a certain calmness and serenity might be the possibility of transferring terminally ill patients to a palliative care service within the same hospital. In the end, they are less often confronted with difficult terminal situations than their French colleagues. After all, one can also consider that the attitude of German doctors who lean easily on the support of palliative care teams has not only positive aspects. Thus, a palliative care doctor told me that some physicians "forsake their patients too early", although there were still treatments that could be tried. According to this doctor, German physicians have a tendency to transfer patients "too quickly" to palliative care services in order to "disengage" from complicated cases. Whatever the doctors' motivation may be, it appears that the absence of moral unease felt by them when withdrawing treatment at a patient's request has an effect on the patients: reinforced in their decisional autonomy, German patients seem to think less often of asking their doctor to put an end to their life. However, although none of the 52 German patients I documented during my ethnographic work asked a doctor to hasten his or her death, every year there are German patients ${ }^{8}$ travelling to Switzerland in order to take up assisted suicide (Burkhardt et al. 2006). A study from 2009 showed also that every third German

\footnotetext{
${ }^{8}$ According to a Swiss report in 2006, 253 German patients have benefited of assisted suicide between 1998 and 2005 (Eidgenössisches Justiz- und Polizeidepartment, 2006, p. 33).
} 
doctor (34\%) received a request for assistance in suicide. Without having any comparative data of the number of requests for euthanasia, this observation and the development of the German debate in the last years (Lipp 2011) reveal that in Germany, the preferred solution in desperate situations seems to be assisted suicide rather than euthanasia. That is, an action ultimately accomplished by the concerned person themselves (albeit with assistance from another) seems preferable to a death administered by a second person. Nevertheless, to date in Germany, a doctor cannot legally provide their patient with a lethal substance and I did not encounter any case like this during my fieldwork. Although euthanasia and assisted suicide share some elements - the patient's will, a request for assistance to die and provision of some assistance-it appears that there is a non-negligible difference between an act accomplished by the interested person himself, even if he gets assistance, and an act accomplished by a second person.

\section{The right to determine one's own death: a question of society}

What does the comparison between France and Germany show? My findings suggest that, in spite of the emphasised differences between the practices in both countries, the common point in their debates is the question concerning a patient's autonomy to choose the conditions under which they would wish to die. As we could see, these conditions depend, amongst others, on the doctor-patient relationship, the organisation of end-of-life care in hospital settings, and more generally, on the way autonomy is defined and handled in the public debate. The very question of determining the moment of one's death is thus only one aspect of the complex situation at the end of life.

From a sociological perspective, it was important to understand in which ways the debate about autonomy at the end-of-life differs in each country. As we can see, in France, the debate focuses on the acquisition of the "right" to die, whereas, in Germany, it is respect of the dying person's will, specifically in the sense of honouring treatment refusal, that is the object of constant concern. It appears then that, in an environment where doctors try less overtly to integrate the patient in therapeutic decisionmaking, the claims for euthanasia emerge more frequently-as is the case in France. That implies that requests for euthanasia are often motivated by the individual's fear of losing autonomy. The requests express the desire of a vulnerable person to reaffirm their liberty-their ultimate liberty in determining their own death. In Germany, the death that is, at the request of the patient, administered by a second person is not perceived as the only means by which the sick person can assert their autonomy. In this country, autonomy consists rather in the liberty an individual has a propos any medical intervention (particularly treatment refusal) and not only in the liberty to claim their own death. However, in the rare cases where death is seen as the last resort response to extreme pain and suffering, it appears that, in Germany, the public discussion focuses instead on the possibility of medical assisted suicide, rather than a lethal injection administered by a doctor. Assisted suicide enables the patient to preserve, until the end, control over interventions executed on his or her body, without delegating this control to a physician. Moreover, any medical act causing the death of a sick person is disapproved by German society and remains a taboo.

What might these sociological insights mean at the legal, policy and ethical levels? If one takes into account the different elements that led to the emergence of the vehement euthanasia debate in France, the question arises whether a law relative to this matter would modify doctors' attitudes towards respecting the patient's will and whether such a law would have a positive impact on the organisation of end-of-life care. Supposing that euthanasia represents the absolute respect of an individual's will one can then question whether French physicians would practice euthanasia in this sense. Yet, if one considers their "active" attitude, then hastening death can be seen as reflective of their attitude towards controlling life, as well as death, via medical techniques. The moral principle of self-determination that is sometimes attributed to euthanasia is therefore put into question and shapes up as not particularly pertinent in the concrete case of France. In this point, the French debate differs from the Dutch situation where respect for patient autonomy has a long tradition even before the law on euthanasia came into force. Whereas in the Netherlands euthanasia cannot be justified without a clear request, neither the French definition of euthanasia nor those French doctors favourable to hastening death under certain circumstances, refer to the patient's explicit wish. However, even in a country like the Netherlands, questions concerning the authenticity of autonomy arise when depressed or psychiatric patients who are not terminally ill are assisted in dying (Dickenson et al. 2010, pp. 24-28).

And what about the argument, surrounding unbearable suffering which is one of the criteria in Dutch law to practice euthanasia? According to a study by Pasman et al. (2009), unbearable suffering consists for most patients not in physical suffering, as perceived by the physicians, but of (fear of) dependency, no longer being able to participate in normal daily life, or mental suffering because of deterioration. In the same way, Seale and Addington-Hall (1994) showed that a doctor-patient relationship where the patient is an autonomous partner in the decision-making process 
influences the patient's will to live. How much then may the unbearable suffering mentioned by French patients depend on a lack of decisional autonomy? Does a physician who ends a life in order to bring an end to an "unbearable" situation really act in the interest of the patient?

One can also challenge the pertinence of the self-determination argument in the German debate about advance decisions. Will the recent law, supposed to enhance patients' autonomy, resolve all the problems related to the final stage of life? One can imagine that there will always be cases where the "last will" of a patient is not clearly known or cannot be easily interpreted and that, in certain cases, the patient's wishes will not be compatible with the doctor's conscience. The priority given to the patient's will entails also the risk of losing an opportunity to cure a disease. Last but not least, there might always be ill persons who would prefer, in spite of good care apparently meeting all their needs, to put an end to their life by having recourse to a lethal drug.

\section{Conclusion}

What I want to stress in this paper is that one should keep in mind that theoretical philosophical arguments that are employed to justify a certain action do not always comprehend all the elements that appear in a concrete situation. This means that even if one could justify euthanasia on a purely theoretical level by reference to the principle of liberty, as it is advocated e.g. by Mill, in practice, matters are more complex. The request for euthanasia does not necessarily concern the right or the liberty to die at a certain moment and by the hand of a second person, but to determine the conditions of one's final stage of life in general. ${ }^{9}$ And the attempt to boost individual choice by legal modifications will not satisfy the exigencies of all individuals within a certain society. In some cases euthanasia might enable autonomy, but in other cases it might not. Thus, beyond ethical arguments, theoretical reflection about these issues should better take into account the outcomes of empirical research exploring when, why and how a question emerges and is perceived as a moral issue. Such analyses permit us to identify the broader social, legal and historical context that affects the question at issue and contribute so to discussing the moral question in a new

\footnotetext{
9 This point is confirmed amongst others by the data from Oregon where physician assisted suicide is authorised since 1994. The principal argument for their request is losing autonomy. Furthermore, only one third of the persons who get prescriptions for lethal medications ultimately take this. These results suggest that some persons only need to be assured that there is the possibility of a quick and self-determined death (State of Oregon 2011).
}

light-without being trapped in the usually dichotomised argumentation (e.g. sanctity of life vs. self-determination). A society which discusses euthanasia legislation should therefore first consider the findings of this and other studies, and faithfully evaluate the existent conditions allowing/not a patient to make autonomous decisions about his or her end-of-life in general and not only about the moment of his or her death.

Acknowledgments The author would like to thank Professor Simone Bateman (Centre de Recherche Sens, Ethique et Société, Paris), Professor Ruud ter Meulen and Dr Richard Huxtable (Centre for Ethics in Medicine, University of Bristol) for their constructive comments on earlier versions of this paper. This paper presents results of a $\mathrm{PhD}$ thesis carried out at the Ecole des Hautes Etudes en Sciences Sociales, Paris, and funded by the Caisse Nationale de l'Assurance Maladie des Travailleurs Salariés, Paris. The author is also grateful to the European Union for funding her current post-doctoral Marie Curie fellowship which permitted writing the present paper. Finally, the author would like to thank the anonymous referees for critical comments and suggestions that led to improvements in the quality of this paper.

\section{References}

ADMD, Association pour le Droit de Mourir dans la Dignité. 2007. Sondages SOFRES 2007. http://www.admd.net/archives/dos siers/sondage-fev07.htm. Accessed 23 February 2011.

Allensbacher Archiv. 2009. IfD-Umfrage 5265. http://www.bunde saerztekammer.de/downloads/Sterbehilfe1.pdf. Accessed 24 February 2011.

Association pour le Droit de Mourir dans la Dignité. 2000. Le point de vue du corps médical. http://www.admd.net/archives/ac tions/pointdevue-medecin.htm. Accessed 28 April 2011.

Assemblée Nationale. 2004. Rapport no 1708. Mission d'information sur l'accompagnement de la fin de vie (1): 141-142.

Bundesgerichtshof. 1StR 357/94. 13.9.1994.

Bundesgerichtshof. XII ZB 2/03. 17.03.2003.

Bundesärztekammer. 2011. Grundsätze der zur ärztlichen Sterbebegleitung. Deutsches Ärzteblatt 108(7): A346-A348.

Burkhardt, S., R. La Harpe, T.W. Harding, and J. Sobel. 2006. Euthanasia and assisted suicide: comparison of legal aspects in Switzerland and other countries. Medicine, Science and the Law 46(4): 287-294.

Cabé, M.-H., O. Blandin, and G. Poutout. 2008. Etat des lieux du dispositif de soins palliatifs au niveau national. Synthèse. Rouen: ATEMIS.

Comité Consultatif National d'Ethique. 2000. Avis no 63. Fin de vie, arrêt de vie, euthanasie.

Courtas, R. 1991. L'intervention de l'individu dans la fin de sa vie. In Biomédecine et devenir de la personne, ed. S. Novaes. Paris: Seuil.

Crane, D. 2009. Sanctity of social life: Physician's treatment of critically ill patients. New Brunswick: Transaction Publishers.

Deliens, L., J.L. Bernheim, and G. van der Wal. 2003. A comparative study of the euthanasia laws of Belgium and the Netherlands. Revue Médicale de Liège 58(7-8): 485-492.

Der Spiegel. 1973-2011. Spiegel Archiv. http://suche.spiegel. $\mathrm{de} /$ suche/index.html? suchbereich=vorspann\&suchbegriff $=$. Acce ssed 20 April 2011.

Deutsches Ärzteblatt. 1998-2007. Dossier. Dokumentation: Sterbehilfe, Euthanasie und Sterbebegleitung. http://www.aerzte blatt.de/v4/dossiers/dossier.asp?id=8. Accessed 23 February 2011. 
Deutsche Hospizstiftung. 2008. Sonder Hospiz Info Brief: Hospizliche Begleitung und Palliative-Care-Versorgung in Deutschland. http://www.hospize.de/docs/hib/Sonder_HIB_01_08.pdf. Accessed 23 February 2011.

Dickenson, D. 1999. Cross-cultural issues in European bioethics. Bioethics 13(3): 249-255.

Dickenson, D., R. Huxtable, and R. Parker. 2010. The Cambridge medical ethics workbook, 2nd ed. Cambridge: Cambridge University Press.

Die Zeit. 1970-2011. Print Archiv. http://www.zeit.de/2011/index. Accessed 23 February 2011.

Dossier de Presse. 1975-2005. Euthanasie, droit à la mort, soins palliatifs en France. Fondation Nationale des Sciences Politiques. Paris.

Dossier de Presse. 1983-2007. Euthanasie. Comité Consultatif National d'Éthique, Paris.

Drittes Gesetz zur Änderung des Betreuungsrechts vom 29.07.2009. BGBI. I: 2286.

Drum, C.E., G. White, G. Taitano, and W. Horner-Johnson. 2010. The Oregon Death with Dignity Act: results of a literature review and naturalistic inquiry. Disability and Health Journal 3(1): 3-15.

Durkheim, E. 2007. Le Suicide. Paris: PUF.

Eidgenössisches Justiz- und Polizeidepartment. 2006. Sterbehilfe und Palliativemedizin - Handlungsbedarf für den Bund? Bern.

Fox, R.C. 2008. The bioethics that I would like to see. Clinical Ethics 3: 25 .

Fox, R.C., and J.P. Swazey. 2008. Observing bioethics. New York: Oxford University Press.

Generaljustizdirektion der Militärregierung des französischen Besatzungsgebietes in Deutschland. 1947. Der Konstanzer Juristentag (2.-5. Juni 1947). Tübingen: Mohr.

Hervieu-Léger, D. 2003. Catholicisme, la fin d'un monde. Paris: Bayard.

Horn, R. 2006. Die Französische Antwort: Ein Überblick über den Verlauf der Sterbehilfe-Debatte in Frankreich. In collaboration with I. Saake, T. Roser, Zeitschrift für medizinische Ethik 3: 281-295.

Horn, R. 2009. Le debat sur l'euthanasie et les pratiques en fin de vie en France et en Allemagne. Une étude comparative. Unpublished doctoral dissertation. Paris: Ecole des Hautes Etudes en Sciences Sociales.

Hufen, F. 2005. In dubio pro dignitate. In Aktive und Passive Sterbehilfe Medizinische, rechtswissenschaftliche und philosophische Aspekte, ed. F. Thiele, 84-85. München: Wilhelm Fink Verlag.

Isambert, F.-A. 1982. Une sociologie de l'avortement est-elle possible? Revue Française de Sociologie 13: 359-381.

Le Monde. 1987-2011. Archives. http://www.lemonde.fr/web/ recherche/0,13-0,1-0,0.html. Accessed 23 February 2011.

Loi no 91-748 du 31 juillet 1991 portant réforme hospitalière. 1991. Journal Officiel 179: 10226.

Loi no 99-477 du 9 juin 1999 visant à garantir le droit à l'accès aux soins palliatifs. 1999. Journal Officiel 132: 8487.
Kant, E. 1998. Grundlegung zur Metaphysik der Sitten. Ditzingen: Reclam.

Lalande, F., Veber, O. 2009. La mort à l'hôpital. Inspection générale des affaires sociales.

Lipp, V., Simon, A. 2011. Beihilfe zum Suizid: Keine ärztliche Aufgabe. Deutsches Ärzteblatt 108(5): A212-A216.

Loi no 2002-303 du 4 mars 2002 relative aux droits des malades et à la qualité du système de santé. 2002. Journal Officiel 54: 4118.

Loi no 2005-370 du 22 avril 2005 relative aux droits des malades et à la fin de vie. 2005. Journal Officiel 59: 7089.

Maehle, A.-H. 2009. Doctors, honour and the law. Medical ethics in imperial Germany. Houndmills, Basingstoke, Hampshire: Palgrave Macmillan.

Mill, J.S. 2005. On liberty. New York: Cosimo classics.

Mino, J.C., and F. Lert. 2003. Le travail invisible des équipes de soutien et conseil en soins palliatifs à domicile. Sciences Sociales et Santé 2(1): 35-54.

Nationaler Ethikrat. 2006. Selbstbestimmung und Fürsorge am Lebensende.

Oberlandesgericht Frankfurt a.M. 20 W 224/98. 5.8.1998.

Pasman, H.R.W., M.L. Rurup, D.L. Willems, and B.D. OnwuteakaPhilipsen. 2009. Concept of unbearable suffering in context of ungranted requests for euthanasia: qualitative interviews with patients and physicians. British Medical Journal 339: b4362.

Schindler T. 2005. Sterbeorte in Deutschland. Deutsche Gesellschaft für Palliativmedizin.

Seale, C., and J. Addington-Hall. 1994. Euthanasia: The role of good care. Social Science and Medicine 40(5): 581-587.

Seitz, D., and O. Seitz. 2004. Die moderne Hospizbewegung in Deutschland auf dem Weg ins öffentliche Bewusstsein-Ursprünge, kontroverse Diskussionen, Perspektiven. Herbholzheim: Centaurus.

Smets, T., J. Bilsen, J. Cohen, M.L. Rurup, E. De Keyser, and L. Deliens. 2009. The medical practice of euthanasia in Belgium and The Netherlands: Legal notification, control and evaluation procedures. Health Policy 90(2-3): 181-187.

State of Oregon Government. 2011. Death with Dignity Act. http:// www.oregon.gov/DHS/ph/pas/. Accessed 23 February 2011.

Sueddeutsche Zeitung. 1992-2011. Archiv. http://archiv.sueddeut sche.de/sueddz/. Accessed 23 February 2011.

TF1. 2008. Les dernières affaires en France. http://lci.tf1.fr/ science/sante/2008-03/dernieres-affaires-france-5519445.html. Accessed 23 February 2011.

Thorns, A., and N. Sykes. 2000. Opioid use in last week of life and implications for end-of-life decision-making. Lancet 356(9227): 398-399.

Thorns, A., and N. Sykes. 2003. The use of opioids and sedatives at the end of life. Lancet Oncology 4(5): 312-318.

Thouvenin, D. 2008. Audition 15 juillet 2008. In Assemblée Nationale. 2005. Rapport d'information fait au nom de la Mission d'évaluation de la loi no 2005-370 du 22 avril 2005 relative aux droits des malades et à la fin de vie (2): 404-405. 